\title{
Investigation of Physiological Effects Induced by Dehydroepiandrosterone in Human Endothelial Cells and Ovarian Cancer Cell Line
}

\author{
İnsan Endotel Hücreleri ve Ovaryum Kanseri Hücre Hattında \\ Dehidroepiandrosteronun Neden Olduğu Fizyolojik Etkilerin Araştırılması
}

\author{
(D) Gül İpek GÜNDOĞAN*, (D Cenk KIG², (D) Meriç KARACAN³ , (D) Hüsniye DOĞRUMAN1 \\ ${ }^{1}$ Istanbul Yeni Yuzyil University Faculty of Medicine, Department of Histology and Embryology, Istanbul, Turkey \\ 2Istanbul Yeni Yuzyil University Faculty of Medicine, Department of Medical Biology and Genetics, Istanbul, Turkey \\ 3Istanbul Yeni Yuzyil University Faculty of Medicine, Department of Gynecology and Obstetrics, Istanbul, Turkey
}

\begin{abstract}
Objectives: Dehydroepiandrosterone (DHEA) is an endogenous hormone that acts as a ligand for several cellular receptors. An age-dependent decline in circulating levels of DHEA is linked to changes in various physiological functions. In gynecological clinical practice, DHEA is commonly prescribed to induce ovulation. Some clinical studies report a positive association between high serum concentrations of DHEA and an increased risk of developing ovarian cancer. However, the in vitro physiological effects of DHEA on ovarian cancerous cells have not been explored thus far. In this study, we aimed to investigate the physiological effects of DHEA treatment (0-200 $\mu \mathrm{M}, 24-72$ hours) on MDAH-2774 human ovarian cancer cell line and primary HuVeC human endothelial cells.

Materials and Methods: The physiological effects of DHEA treatment (0-200 $\mu \mathrm{M}, 24-72$ hours) on MDAH-2774 human ovarian cancer cell line and primary HuVeC human endothelial cells were investigated with the (3-(4,5-dimethylthiazol-2-yl)-2,5-diphenyltetrazolium bromide) test, acridine orange/ethidium bromide staining, and scratch assay.

Results: DHEA treatment promoted proliferation of the MDAH-2774 cancer cell line in a dose-dependent manner $(r=0.6906, p<0.0001$, for 24 hours) ( $r=0.6802$, $p<0.0001$, for 48 hours) ( $r=0.7969$, $p<0.0001$, for 72 hours). In contrast, DHEA inhibited proliferation of the primary HuVeC cells ( $r=0.9490, p<0.0001$, for 24 hours) ( $r=0.9533, p<0.0001$, for 48 hours) ( $r=0.9584, p<0.0001$, for 72 hours). In agreement with these observations, DHEA treatment resulted in a dose-dependent increase in the number of necrotic cells in the primary HuVeC cells $(r=0.97, p<0.0001)$. However, the number of necrotic or apoptotic cells did not change significantly when the MDAH-2774 cells was exposed to DHEA. Moreover, we found that DHEA treatment reduced the migration rate of $\mathrm{HuVeC}$ cells in a dose-dependent manner $(r=0.9868, p<0.0001)$, whereas only a slight increase was observed in the MDAH-2774 ovarian cancer cell line ( $r=0.8938, p<0.05)$.

Conclusion: Our findings suggest that DHEA promotes the proliferation of ovarian cancer cells in a dose-dependent manner in vitro. Moreover, DHEA induced necrosis and inhibited proliferation in endothelial cells. Although mechanistic evidence is required, our preliminary findings imply that exposure to high doses of DHEA may be associated with an increased risk of developing ovarian cancer.
\end{abstract}

Key words: Dehydroepiandrosterone, MDAH-2774, HuVeC, ovarian cancer

öz

Amaç: Dehidroepiandrosteron (DHEA), bir dizi hücresel reseptör için ligand olan bir endojen bir hormondur. Fizyolojik işlevlerdeki değişiklikler, dolaşımdaki DHEA seviyelerinde yaşa bağlı gerçekleşen düşüşe bağlıdır. Jinekolojik klinik uygulamada DHEA genellikle ovulasyon indüksiyonu için reçetelenmektedir. Bazı klinik çalışmalar, yüksek serum DHEA konsantrasyonları ile ovaryum kanseri gelişme riskinde artış arasında pozitif bir ilișki olduğunu bildirmiştir. Ancak, DHEA'nın over kanseri hücreleri üzerindeki in vitro fizyolojik etkileri şimdiye kadar araştırılmamıştır. Bu çalışmada, DHEA inkübasyonunun (0-200 $\mu \mathrm{M}, 24-72$ saat) MDAH-2774 insan over kanseri hücre hattı ve primer HuVeC insan endotel hücreleri üzerindeki fizyolojik etkileri araştırılmıştır.

Gereç ve Yöntemler: DHEA inkübasyonunun (0-200 $\mu \mathrm{M}, 24-72$ saat) MDAH-2774 insan over kanseri hücre hattı ve primer HuVeC insan endotel hücreleri üzerindeki fizyolojik etkileri (3-(4,5-dimetiltiyazol-2-il)-2,5-difeniltetrazolyum bromür) testi, akridin turuncusu/etidyum bromür boyaması ve yara iyileșme testi ile araștırılmıştır. 
Bulgular: DHEA inkübasyonu, doza bağlı bir şekilde MDAH-2774 kanser hücre hattının proliferasyonunu indüklemiştir ( $r=0,6906,24$ saat boyunca, $p<0,0001)(r=0,6802,48$ saat boyunca $p<0,0001)(r=0,7969, p<0,0001,72$ saat). Tam tersine, DHEA primer HuVeC hücrelerinin proliferasyonunu ise inhibe etmiştir $(r=0,9490,24$ saat için p<0,0001) ( $r=0,9533, p<0,0001,48$ saat için) ( $r=0,9584, p<0,0001,72$ saat için). Bu sonuçları destekler şekilde, DHEA uygulaması HuVeC hücrelerinde nekrotik hücre sayısını doz bağımlı bir şekilde artırmıştır ( $r=0,97, p<0,0001)$. Ancak, DHEA'ya maruz kalan MDAH-2774 hücre hattında nekrotik veya apoptotik hücre sayısı önemli ölçüde değișmemiștir. Ayrıca, DHEA inkübasyonunun HuVeC hücrelerinin migrasyon oranını doz bağımlı bir şekilde azaltırken ( $r=0,9868, p<0,0001)$, MDAH-2774 over kanseri hücre hattında az bir oranda artırmıştır $(r=0,8938, p<0,05)$.

Sonuç: Bulgularımız DHEA'nın in vitro olarak over kanseri hücrelerinin doz bağımlı bir şekilde çoğalmasını artırdığını göstermektedir. Ayrıca, DHEA endotelyal hücrelerinde nekrozu indüklemiş ve proliferasyonu inhibe etmiștir. Her ne kadar mekanistik veri gerekse de, ön bulgularımız, yüksek dozlardaki DHEA maruziyetinin over kanseri geliştirme riskiyle ilișkili olabileceğini göstermektedir.

Anahtar kelimeler: Dehidroepiandrosteron, MDAH-2774, HuVeC, ovaryum kanseri

\section{INTRODUCTION}

Dehydroepiandrosterone (DHEA) is one of the most abundant circulating steroid hormones produced by adrenal glands ${ }^{1}$ and it can also serve as a precursor of other steroids in the brain. ${ }^{2}$ DHEA is involved in the biosynthesis of sex steroids, and it may act as a ligand for several nuclear receptors as well as G-protein-coupled receptors. Physiological levels of DHEA in human serum range between 1 and $1000 \mathrm{~nm},{ }^{3}$ whereas prescribed pharmacological doses range between 10 and 100 $\mu \mathrm{M} .{ }^{4}$ An age-dependent decline in circulating levels of DHEA can induce changes in cardiovascular tissues, ${ }^{5}$ female fertility, ${ }^{6}$ and metabolic and neuronal/central nervous system functions. ${ }^{7}$

Clinical findings show that DHEA administration can increase serum androgen levels, improve mood, improve sexual function, and decrease fatigue. ${ }^{8}$ DHEA is also widely used to induce ovulation in gynecological clinical practice. However, data also suggest that high doses or prolonged use of DHEA is associated with an increased risk of developing ovarian cancer. ${ }^{910}$ Cameron and Braunstein ${ }^{8}$ have reported that DHEA activates estrogen receptors ${ }^{11}$ in breast cancer and endothelial cell lines..$^{4,12,13}$ In line with these observations, clinical findings also implicate DHEA as a risk factor for developing breast cancer. ${ }^{14}$ In contrast, in vitro findings suggest an inhibitory effect of DHEA on the proliferation of breast, myeloma, hepatoma, prostate, human colon adenocarcinoma, cervical, and leukemia cancer cell lines. ${ }^{15-21}$ Thus, our understanding of the role of DHEA as a risk factor for developing cancer is limited.

At present, the in vitro effects of DHEA on normal and ovarian cancer cell lines have not been compared. Therefore, we aimed to investigate the physiological effects of DHEA on MDAH2774 human ovarian cancer and non-cancerous HuVeC human endothelial cell lines. A better understanding of the differential effects of DHEA on normal and cancer cell lines can have important implications in clinical research.

\section{MATERIALS AND METHODS}

\section{Cell culture and chemicals}

Human ovarian carcinoma epithelial cell [MDAH-2774 (ATCC ${ }^{\circledR}$ CRLM10303 $3^{\text {TH }}$ ] and human umbilical vein endothelial [HUVEC-C (HuVeC) ATCC ${ }^{\otimes}$ CRL-1730 $\left.{ }^{\mathrm{TM}}\right)$ ] cell lines were used. The cell lines were cultured in high-glucose Dulbeccos modified eagle medium (DMEM) (Sigma, 5546) supplemented with $1 \% 2 \mathrm{mM}$ L-glutamine (Biological Industries, BI03-020-1B), P/S (50 U/mL penicillin and $50 \mu \mathrm{g} / \mathrm{mL}$ streptomycin; Biological Industries, 03031-1B), 10\% fetal bovine serum (Biowest, S1810-500). Each cell line was seeded into $10 \mathrm{~cm}$ plates $\left(1.5 \times 10^{6}\right.$ cells/plate) and Biotest divided 72 hours later. DHEA tablets [approximately $0.6-$ $1.2 \mathrm{~g}$ (2-3 pieces)] were dissolved in $50 \mathrm{~mL}$ of absolute ethanol as stock solutions. A $0.45-\mu \mathrm{m}$ membrane filter was used for sterilization and the solution prepared fresh for every test. ${ }^{4}$ As a negative control, cells were treated with ethanol (the solvent of DHEA) containing DMEM.

\section{(3-(4,5-dimethylthiazol-2-yl)-2,5-diphenyltetrazolium bromide) (MTT) assay}

$12 \mathrm{mM}$ stock solution of MTT (Neofrox 3580 MTT) was prepared as described by Mosmann. ${ }^{22}$ Cells were seeded into each well of a 96-well plate (approximately $10^{4}$ cells/well) in a volume of $100 \mu \mathrm{L}$. The MTT assay was conducted as follows: $10 \mu \mathrm{L}$ of 12 mM MTT stock solution was added to each well and incubated at $37^{\circ} \mathrm{C}$ for 4 hours. Cell-free wells containing only $100 \mu \mathrm{L}$ of medium were included as negative controls. After incubation with MTT for 4 hours, $75 \mu \mathrm{L}$ of medium was removed from the wells, and the formazan crystals were then dissolved in $50 \mu \mathrm{L}$ of DMSO by mixing the wells with a pipette. After a further 10 minutes of incubation at $37^{\circ} \mathrm{C}$, the samples were mixed briefly again and the absorbance recorded at $540 \mathrm{~nm}$.

\section{Acridine orange/ethidium bromide $(A O / E t B r)$ dual staining}

The $\mathrm{AO} / \mathrm{EtBr}$ dual staining technique was performed as described by Liu et al. ${ }^{23}$ Briefly, the cells were seeded in a 96well plate at a density of approximately $10^{4}$ cells per well. After 48 hours of incubation with DHEA, the cells were trypsinized, and 10-25 $\mu \mathrm{l}$ of the cell suspension was transferred to glass slides. One microliter of $\mathrm{AO} / \mathrm{EtBr}$ staining (dye mixture containing 100 $\mu \mathrm{g} / \mathrm{mL} \mathrm{AO}$ and $100 \mu \mathrm{g} / \mathrm{mL} \mathrm{EtBr}$ ) solution was added to the cell suspension, and then the sample was covered with a cover glass. Within 20 minutes after addition of AO/EtBr dye, the cell morphology was checked under a fluorescence microscope (Carl-Zeiss/Axio Observer 3., Zen 2.3 Blue Edition software). For statistical analysis, at least 200 cells were counted and the results expressed as the average of at least three independent experiments. Both live and dead cells stained with $A O$, while only the dead cells that had lost membrane integrity stained with ethidium bromide. Living cells appeared uniformly green, while cells that were in the early apoptotic stage showed green dots in their nuclei. Late apoptotic cells stained orange and showed nuclear condensation and/or frequent fragmentation. Necrotic 
cells stained orange, and their nuclear morphology was similar to that of living cells, but without concentrated chromatin. ${ }^{23}$

\section{In vitro scratch assay}

The in vitro scratch assay was carried out to evaluate the migration rates according to the protocol described by Liang et al. ${ }^{24}$ Briefly, the surface of the wells in a 6-well plates was scratched with a $10 \mu \mathrm{L}$ sterile pipette tip. After gentle washing with culture medium, images of the scratches at 0-24 hours were taken under a microscope with a magnification of $10 x$ (Carl-Zeiss/Axio observer 3). By using ImageJ software, the gap size was analyzed and the cell migration rate calculated by comparing the cell-free areas of scratches at 24 hours after injury and the scratched areas at 0 hours. The results are expressed as the average of three repeated experiments.

\section{Statistical analysis}

Statistical analysis was performed using GraphPad (Prism 5) software. The statistical significance of differences between groups was assessed by One-Way ANOVA and Tukey's posthoc test $(n=3)$.

\section{RESULTS}

First, we investigated the effects of DHEA on cell viability by comparing the changes in proliferation rates of MDAH-2774 (human ovarian carcinoma epithelial cell) and HuVeC (human non-cancerous umbilical vein endothelial) cell lines. For this purpose, we used the MTT assay, which is a relatively simple and well-established procedure for the evaluation of cell viability and proliferation. ${ }^{25}$ We tested the effects of four different concentrations ( $10 \mu \mathrm{M}, 50 \mu \mathrm{M}, 100 \mu \mathrm{M}$, and $200 \mu \mathrm{M})$ of DHEA for 24,48 , and 72 hours. The concentration range was determined according to literature data. ${ }^{4}$

Data analysis obtained from the MTT assay showed that DHEA treatment $(10-200 \mu \mathrm{M})$ promoted the proliferation of the MDAH2774 cell line in a dose-dependent manner $(r=0.6906, p<0.0001$, for 24 hours; $r=0.6802$, $p<0.0001$, for 48 hours; $r=0.7969$, $\mathrm{p}<0.0001$, for 72 hours). In contrast to the MDAH-2774 ovarian cancer cell line, DHEA treatment inhibited proliferation of the non-cancerous HuVeC cells. Although, $10 \mu \mathrm{M}$ (24 hours) DHEA treatment did not appear to affect the rate of cell proliferation, higher doses of DHEA ( $\geq 50 \mu \mathrm{M}$ for 24,48 , and 72 hours) significantly inhibited proliferation of $\mathrm{HuVeC}$ cells in a dosedependent fashion ( $r=0.9490$, $p<0.0001$, for 24 hours; $r=0.9533$, $p<0.0001$, for 48 hours; $r=0.9584, p<0.0001$, for 72 hours) (Figure 1b, $d, f$ ).

As seen in Figure 1, 48 and 72 hours of DHEA exposure had the greatest effect on cell proliferation. In this context, to avoid the possible toxic effects that might arise due to prolonged drug exposure, we selected 48 hours as the optimum exposure time. Thus, subsequent experiments were carried out by exposing the cells to $10 \mu \mathrm{M}, 50 \mu \mathrm{M}, 100 \mu \mathrm{M}$, and $200 \mu \mathrm{M}$ DHEA for 48 hours.

Next, we used the $\mathrm{AO} / \mathrm{EtBr}$ dual staining protocol to compare changes in the ratio of apoptotic/necrotic cells. Dual AO/ EB staining is a reliable and inexpensive technique to detect apoptotic and necrotic cells in cell culture experiments. ${ }^{23}$ The changes in the ratio of apoptotic and necrotic cells were evaluated upon exposure to DHEA (10-200 $\mu \mathrm{M}$ for 48 hours). Our findings demonstrated that DHEA treatment did not induce apoptosis or necrosis in MDAH-2774 cells (Figure 2a, b). On the other hand, we detected a dose-dependent increase in the number of necrotic cells when $\mathrm{HuVeC}$ cells were treated with DHEA (48 hours, by $5 \% \pm 1 \%$ for $10 \mu \mathrm{M}, 14.33 \% \pm 6 \%$ for 50 $\mu \mathrm{M}, 32 \% \pm 3 \%$ for $100 \mu \mathrm{M}, 54.33 \% \pm 5 \%$ for $200 \mu \mathrm{M}, \mathrm{p}<0.05)$. Suggesting that DHEA treatment induces necrotic death in the HuVeC cell line. Representative microscope images from AO/ EtBr-stained samples are shown in Figure 3.

Then, we investigated whether or not DHEA treatment could cause changes in cell migration rates. To this end, we a

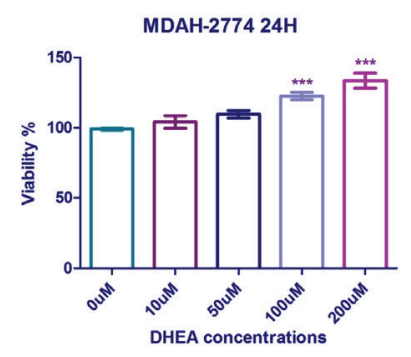

C

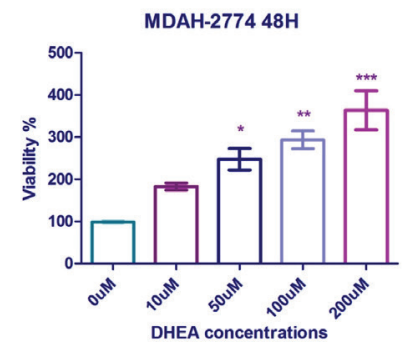

e

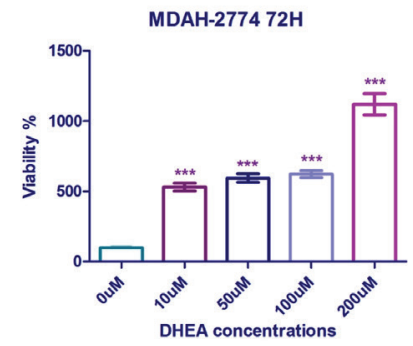

b

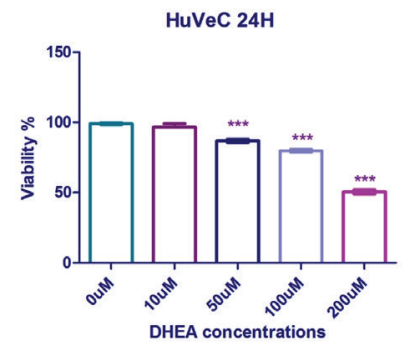

d

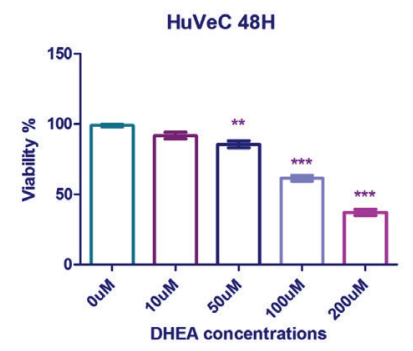

f

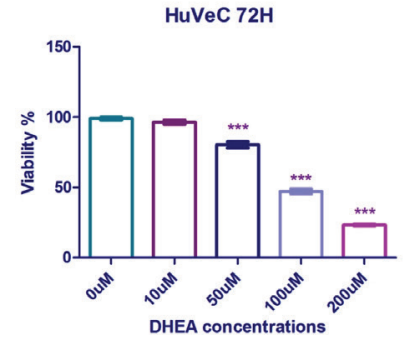

Figure 1. The effect of DHEA on cell proliferation. a, c, e) MDAH-2774 ovarian cancer and b, d, f) HuVeC endothelial cell lines were treated with dehydroepiandrosterone for 24,48 , and 72 hours in an incubator. MTT assays were performed 24,48 , and 72 hours after treatment with the indicated doses of DHEA relative \% changes in proliferation rates were compared against the non-treated control group $(0 \mu \mathrm{M})$, and statistical significance was tested using One-Way ANOVA followed by Tukey's multiple-comparison test $\left(*,{ }^{* *},{ }^{* * *} p<0.0001, n=6\right)$. The correlation between DHEA dose and its effect on proliferation was analyzed by linear regression (GraphPad Prism program). MDAH: $r=0.6906, p<0.0001$, for 24 hours; $r=0.6802, p<0.0001$, for 48 hours; and $r=0,7969, p<0.0001$ for 72 hours. HuVeC: $r=0.9490, p<0.0001$ for 24 hours; $r=0.9533, p<0.0001$, for 48 hours; and $r=0,9584, p<0.0001$ for 72 hours. DHEA: Dehydroepiandrosterone, MTT: (3-(4,5-dimethylthiazol-2yl)-2,5-diphenyltetrazolium bromide) 
a

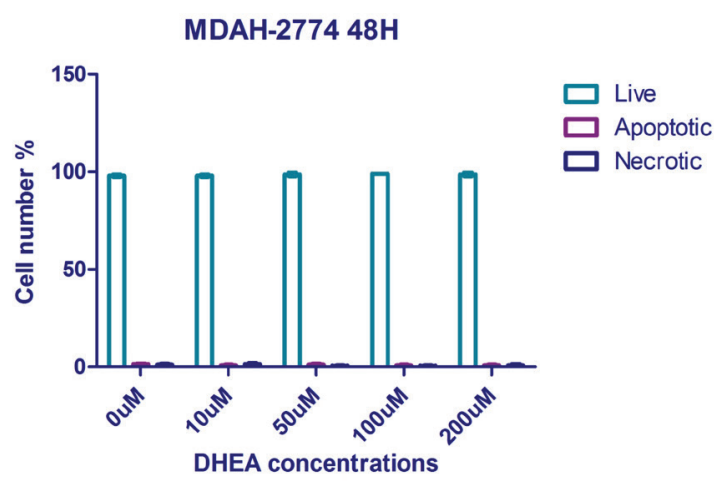

b

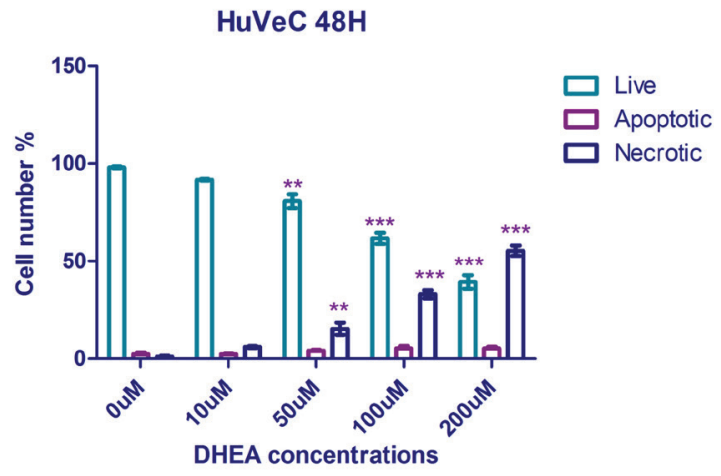

Figure 2. DHEA induces necrosis at high concentrations. a) MDAH-2774, and b) HuVeC endothelial cell lines were treated with 10-200 $\mu \mathrm{M}$ DHEA for 48 hours in an incubator. $\mathrm{AO} / \mathrm{EtBr}$ double staining was performed 48 hours after treatment with the indicated doses of DHEA. Percent changes in the ratio of necrotic cells were compared against the non-treated control group $(0 \mu \mathrm{M})$, and statistical significance was tested using One-Way ANOVA followed by Tukey's multiple-comparisons test. ${ }^{* *},{ }^{* * *}$ : $p<0.05, n=3$, DHEA: Dehydroepiandrosterone, AO/EtBr: Acridine orange/ethidium bromide
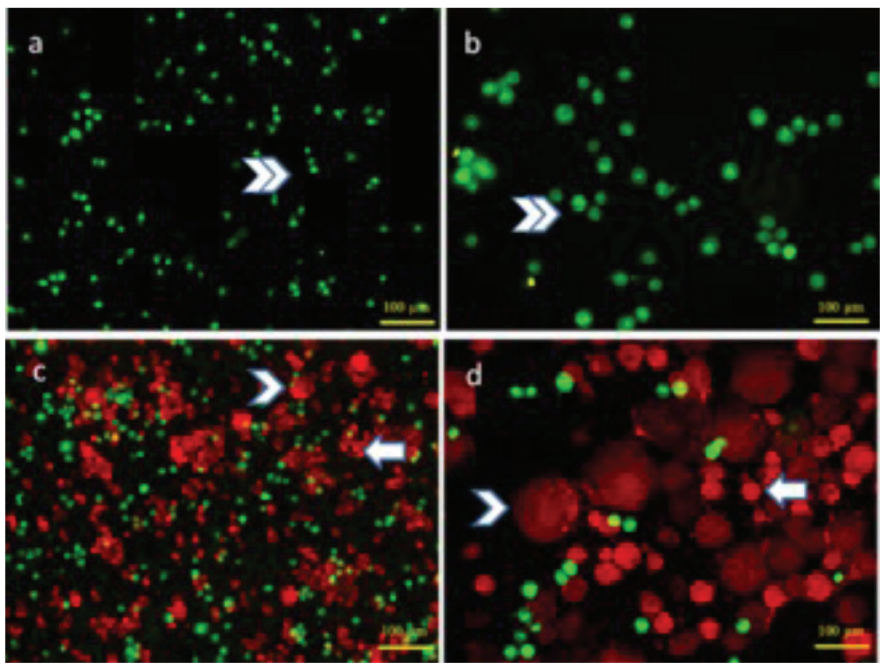

Figure 3. Representative microscope images from $A O / E t B r$ double staining. a) Magnification: 10x, MDAH-2774 cells (control: $0 \mu \mathrm{M}$ DHEA), b) magnification: $40 x, M D A H-2774$ cells $(100 \mu M$ DHEA), c) magnification: 10x, HuVeC cells (100 $\mu \mathrm{M}$ DHEA), d) magnification: 40x, HuVeC cells (100 $\mu \mathrm{M}$ DHEA). Arrows point to apoptotic cells, arrow heads point to necrotic cells, and double arrow heads point to live cells. AO/EtBr: Acridine orange/ ethidium bromide performed the scratch assay. This is a simple in vitro method that serves as a powerful tool for analyzing cell migration rates in two dimensions. ${ }^{26}$ In this context, we tested the effect of 10 $200 \mu \mathrm{M}$ DHEA (48 hours) treatment on cell migration rates by the in vitro scratch assay protocol. Our findings indicated that DHEA treatment triggered a slight increase in the migration rate of MDAH-2774 ovarian cancer cells (48 hours, by $7 \% \pm$ $1 \%$ for $10 \mu \mathrm{M}, 8 \% \pm 1 \%$ for $50 \mu \mathrm{M}, 9 \% \pm 1 \%$ for $100 \mu \mathrm{M}, 10 \% \pm$ $1 \%$ for $200 \mu \mathrm{M}, \mathrm{p}<0.05$ ) (Figure $4 \mathrm{a}$ ). In contrast, DHEA reduced the migration rate of non-cancerous $\mathrm{HuVeC}$ cells in a dosedependent manner (48 hours, by $5 \% \pm 3 \%$ for $10 \mu \mathrm{M}, 14 \% \pm 1 \%$ for $50 \mu \mathrm{M}, 31 \% \pm 3 \%$ for $100 \mu \mathrm{M}, 52 \% \pm 4 \%$ for $200 \mu \mathrm{M}, \mathrm{p}<0.05$ ) (Figure 4b). Representative microscope images from scratch assay experiments are shown in Figure 5.

\section{DISCUSSION}

DHEA is one of the most widespread adrenal steroids in humans. DHEA is the precursor of bioactive steroids, such as estrogen and testosterone. ${ }^{27}$ Although DHEA is shown to be capable of activating estrogen receptors, 11 it can also act independently

a

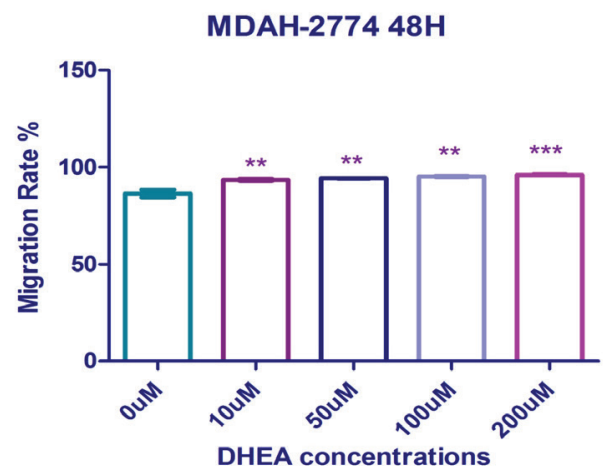

b

$\mathrm{HuVeC} 48 \mathrm{H}$

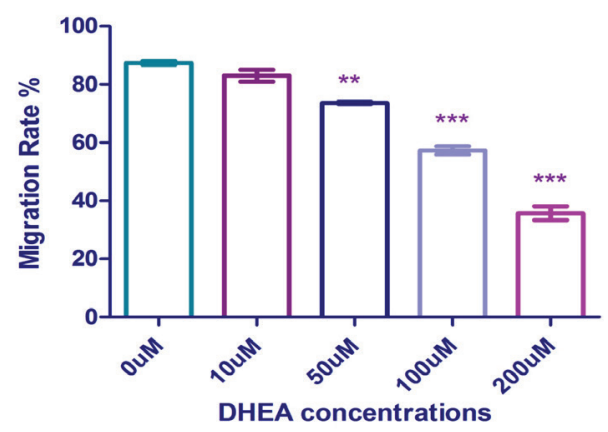

Figure 4. DHEA reduces the cell migration rate at high concentrations in $\mathrm{HuVeC}$ and increases the migration rate in MDAH-2774. a) MDAH2774 , b) HuVeC endothelial cell lines were treated with 10-200 $\mu \mathrm{M}$ DHEA for 48 hours in an incubator. A scratch assay was performed 48 hours after treatment with the indicated doses of DHEA. The rate of migration (how soon the gap closes) in 48 hours was calculated by measuring the gap at 0 and 48 hours after scratching the plates. Percent changes in the migration rates were compared against the non-treated control group $(0 \mu \mathrm{M})$, and statistical significance was tested using One-Way ANOVA followed by Tukey's multiple-comparison test. ${ }^{*},{ }^{* *},{ }^{* *}$ : $p<0.05, n=3$, DHEA: Dehydroepiandrosterone 
of estrogen and androgen receptors in endothelial and breast cancer cells., ${ }^{4,12,13}$ In gynecological clinical practice, DHEA is also prescribed to induce ovulation. There are conflicting findings as to the role of DHEA as a risk factor for developing cancer. Higher levels of DHEA have been correlated with an increased risk of developing breast cancer. ${ }^{28}$ On the other hand, Yoshida et al. ${ }^{29}$ proposed that DHEA can reduce the risk of developing breast cancer by blocking estrogen receptors. For the most part, DHEA appears to inhibit the proliferation of cancer cells, according to in vitro findings. ${ }^{15-21}$ Several different groups have demonstrated that DHEA inhibits the proliferation of hepatoma, breast, myeloma, prostate, human colon adenocarcinoma, leukemia, and cervical cancer cell lines..$^{15-21}$ On the other hand, clinical data also suggests that DHEA may be positively associated with breast cancer. ${ }^{14}$ For example, Michels et al. ${ }^{30}$ have identified an increased risk of endometrial cancer with high levels of adrenal androgens and estrogens. A review of the literature revealed that sufficient data were not available regarding the in vitro physiological effects of DHEA on ovarian cancer cell lines.

MDAH-2774 is a widely used ovarian cancer cell line ${ }^{31}$ with a high mean tumor volume and is accepted as a suitable model for human ovarian cancer. ${ }^{32}$ Endothelial cells are one of the key players in maintaining physiological hemostasis ${ }^{33}$ and are involved in many important processes, including regulation of cell migration, proliferation, and apoptosis. ${ }^{34}$ Therefore, we have chosen a well-established endothelial cell model, the HUVEC cell line, as a non-cancerous cell model. In this context, we investigated the physiological effects of DHEA on MDAH2774 human ovarian cancer cells in comparison with the noncancerous HuVeC human endothelial cell line.

We have assessed the effect of DHEA on cell proliferation via the MTT assay, which is a relatively simple and well-established procedure for evaluating cell viability. ${ }^{25}$ Our findings revealed that DHEA inhibits proliferation in the non-cancerous HuVeC cells in a dose-dependent manner (Figure 1). In line with our observation, Liu et al. ${ }^{35}$ showed that DHEA inhibited cell proliferation of non-cancerous primary rat Leydig cells. They suggested that this cell type-specific response could be due to the differences in the way DHEA was processed or metabolized

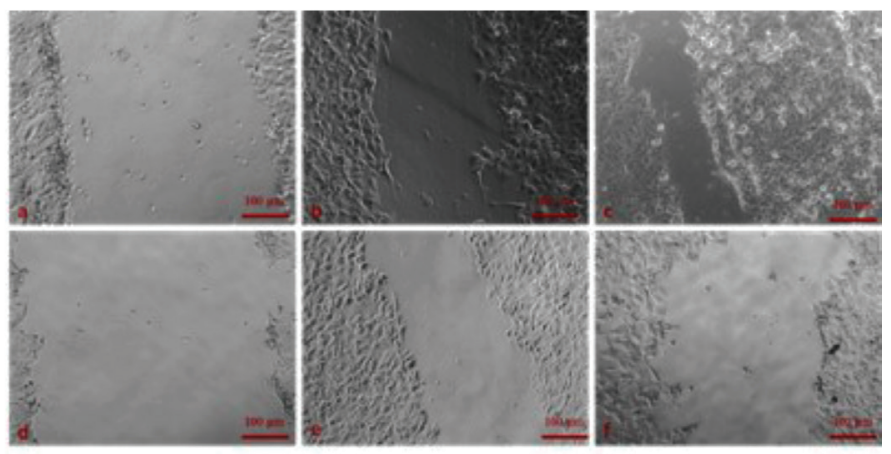

Figure 5. Representative microscope images from in vitro scratch assay (magnification 10x). a) 0 hour MDAH-2774 cells, b) 48 hour $0 \mu \mathrm{M}$ DHEA, MDAH-2774 cells, c) 48 hour $100 \mu \mathrm{M}$ DHEA, MDAH-2774 cells, d) 0 hour HuVeC cells, e) 48 hour $0 \mu \mathrm{M}$ DHEA, HuVeC cells, f) 24 hour $100 \mu \mathrm{M}$ DHEA, HuVeC cells. DHEA: Dehydroepiandrosterone inside the cell. Surprisingly, we found that DHEA promoted proliferation of MDAH-2774 cancer cells in a dose-dependent manner (Figure 1). This finding supports the notion that DHEA may exert its effect in a cell type-specific manner. Similarly, Joshi et al. ${ }^{36}$ reported cell type-specific differential effects of DHEA between mouse and human melanoma cell lines.

We have employed dual AO/EB staining technique to assess the DHEA-induced effects on apoptotic activity in cells. ${ }^{23}$ We did not observe a significant change in the number of necrotic or apoptotic cells in the ovarian cancer cell line MDAH-2774 (Figure 2). However, our findings revealed that DHEA can induce necrotic cell death in the non-cancerous $\mathrm{HuVeC}$ cell line. Girón et al. ${ }^{19}$ previously reported that DHEA treatment induced both apoptotic and necrotic cell death in cervical cancer cell lines. Interestingly, supplementation of the medium with DHEA was reported to increase the number of primordial follicles by inhibiting apoptotic activity in mice. ${ }^{37}$ In contrast, Kim et al..$^{38}$ demonstrated that DHEA administration can induce apoptosis in the mouse ovaries. More recent evidence also suggests that DHEA supplementation can protect ovarian cells in rats rather than inducing apoptotic activity. ${ }^{39}$ Similarly, DHEA was found to inhibit $\mathrm{H}_{2} \mathrm{O}_{2}$-induced oxidative stress damage and apoptosis in Leydig cells. ${ }^{40}$ The presence of contradictory findings further supports the idea that DHEA can exert its effects in a cell-typespecific manner.

Available data on the signaling mechanisms involved in DHEAmediated physiological changes are also scarce. Girón et al. ${ }^{19}$ suggested that DHEA can exert its effects through the mitogenactivated protein kinase signaling pathway, independently of either estrogen receptor or androgen receptor. Jimenez et al. ${ }^{41}$ showed that DHEA may inhibit the pentose phosphate pathway and thereby alter oocyte lipid metabolism in mice. DHEA is shown to be able to directly act on plasma membrane receptors, such as the G-protein-coupled receptor in endothelial cells and aminobutyric-acid-type A in neurons. DHEA also binds androgen and estrogen receptors and can inhibit voltage-gated T-type calcium channels. ${ }^{42}$ Nevertheless, molecular and mechanistic approaches are necessary to dissect the mechanisms involved in this cell type-specific action of DHEA.

Previously, the migration of cervical cancer cell lines was found to be suppressed by DHEA. ${ }^{43}$ In line with these reports, LópezMarure et al. ${ }^{20}$ proposed that DHEA inhibited the proliferation of all breast cancer cell lines. Consistently, we found that DHEA treatment can reduce the migration rate of non-cancerous HuVeC cells in a dose-dependent manner (Figure 4). Curiously, however, we detected a slight increase in the migration rate of the MDAH-2774 ovarian cancer cell line (Figure 4). This observation suggests that DHEA may induce the migration of ovarian cancer cells. In agreement with our observations, Montt-Guevara et al. ${ }^{44}$ showed that DHEA stimulates cell invasion via moesin activation in the T47D breast cancer cell line.

\section{Study limitations}

In this study, we presented reproducible data to support our observations as to the physiological effects of DHEA on ovarian 
cancer and non-cancerous cells. However, we were not able to provide insight into the underlying molecular mechanisms and pathways due to a lack of molecular evidence. We were not able to provide mechanistic evidence to support our descriptive findings.

\section{CONCLUSION}

Although DHEA inhibited proliferation of the non-cancerous HuVeC cells, DHEA treatment was able to promote the proliferation of the MDAH-2774 cancer cell line in a dosedependent manner. We detected a dose-dependent increase in the number of necrotic cells in the non-cancerous HuVeC cell line in response to DHEA treatment. However, the number of necrotic or apoptotic cells did not change significantly in the MDAH-2774 cell line. DHEA treatment reduced the migration rate of non-cancerous $\mathrm{HuVeC}$ cells, whereas only a slight increase was observed in the MDAH-2774 ovarian cancer cell line. Our findings suggest that DHEA promotes the proliferation of ovarian cancer cells in a dose-dependent manner in vitro. Moreover, we found that DHEA induced necrosis and inhibited proliferation in a non-cancerous endothelial cell line. Although molecular and mechanistic evidence is required, our preliminary findings imply that exposure to high doses of DHEA may be associated with an increased risk of developing ovarian cancer.

Conflicts of interest: No conflict of interest was declared by the authors. The authors alone are responsible for the content and writing of the paper.

\section{REFERENCES}

1. Turcu A, Smith JM, Auchus R, Rainey WE. Adrenal androgens and androgen precursors-Definition, synthesis, regulation and physiologic actions. Compr Physiol. 2014;4:1369-1381.

2. Trainor BC, Nelson RJ. Neuroendocrinology of aggression [Internet]. In: Handbook of Neuroendocrinology. Academic Press. 2012;509-520.

3. Young J, Couzinet B, Nahoul K, S Brailly, Chanson P, Baulieu EE, Schaison G. Panhypopituitarism as a model to study the metabolism of dehydroepiandrosterone (DHEA) in humans. J Clin Endocrinol Metab. 1997;82:2578-2585.

4. Zapata E, Ventura JL, De La Cruz K, Rodriguez E, Damián P, Massó F, Montaño LF, López-Marure R. Dehydroepiandrosterone inhibits the proliferation of human umbilical vein endothelial by enhancing the expression of p53 and p21, restricting the phosphorylation of retinoblastoma protein, and is androgen- and estrogen-receptor independent. FEBS J. 2005;272:1343-1353.

5. Ohlsson C, Vandenput L, Tivesten. DHEA and mortality: What is the nature of the association? J Steroid Biochem Mol Biol. 2015;145:248253

6. Tartagni M, Cicinelli MV, Baldini D, Tartagni MV, Alrasheed H, DeSalvia MA, Loverro G, Montagnani M. Dehydroepiandrosterone decreases the age-related decline of the in vitro fertilization outcome in women younger than 40 years old. Reprod Biol Endocrinol. 2015;13:18.

7. Maggio M, De Vita F, Fisichella A, Colizzi E, Provenzano S, Lauretani F, Luci M, Ceresini G, Dall'Aglio E, Caffarra P, Valenti G, Ceda GP. DHEA and cognitive function in the elderly. J Steroid Biochem Mol Biol. 2015;145:281-292.

8. Cameron DR, Braunstein GD. The use of dehydroepiandrosterone therapy in clinical practice. Treat Endocrinol. 2005;4:95-114.

9. Helzlsouer KJ, Gordon GB, Alberg AJ, Bush TL, Hoffman SC, Longcope C, Comstock GW. Serum gonadotropins and steroid hormones and the development of ovarian cancer. JAMA.1995;274:1926-1930.

10. Ose J, Poole EM, Schock H, Lehtinen M, Arslan AA, Zeleniuch-Jacquotte A, Visvanathan K, Helzlsouer K,Buring JE, Lee IM, Tjønneland A, Dossus L, Trichopoulou A, Masala G, Onland-Moret NC, Weiderpass E, Duell EJ, Idahl A, Travis RC, Rinaldi S, Merritt MA, Trabert B, Wentzensen N,Tworoger SS, Kaaks R, Fortner RT. Androgens are differentially associated with ovarian cancer subtypes in the Ovarian Cancer Cohort Consortium. Cancer Res. 2017;77:3951-3960.

11. Chen F, Knecht K, Birzin E, Fisher J, Wilkinson H, Mojena M, Moreno CT, Schmidt A, Harada S, Freedman LP, Reszka AA. Direct agonist/antagonist functions of dehydroepiandrosterone. Endocrinology. 2005;146:45684576.

12. Gayosso V, Montano LF, López-Marure R. DHEA-induced antiproliferative effect in MCF-7 cells is androgen- and estrogen receptor-independent. Cancer J. 2006;12:160-165.

13. Liu D, Iruthayanathan M, Homan LL, Wang Y, Yang L, Wang Y, Dillon J. Dehydroepiandrosterone stimulates endothelial proliferation and angiogenesis through extracellular signal-regulated kinase 1/2-mediated mechanisms. Endocrinology. 2008;149:889-898.

14. Tworoger SS, Sluss P, Hankinson SE. Association between plasma prolactin concentrations and risk of breast cancer among predominately premenopausal women. Cancer Res. 2006;66:2476-2482.

15. Catalina F, Milewich L, Kumar V, Bennett M. Dietary dehydroepiandrosterone inhibits bone marrow and leukemia cell transplants: role of food restriction. Exp Biol Med. 2003;228:1303-1320.

16. Jiang Y, Miyazaki T, Honda A, Hirayama T, Yoshida S, Tanaka Matsuzaki Y. Apoptosis and inhibition of the phosphatidylinositol 3-kinase/Akt signaling pathway in the anti-proliferative actions of dehydroepiandrosterone. J Gastroenterol. 2005;40:490-497.

17. Arnold JT, Liu X, Allen JD, Le H, McFann KK, Blackman MR. Androgen receptor or estrogen receptor- $\beta$ blockade alters DHEA-, DHT-, and E2induced proliferation and PSA production in human prostate cancer cells. Prostate. 2007;67:1152-1162.

18. Ho HY, Cheng ML, Chiu HY, Weng SF, Chiu DTY. Dehydroepiandrosterone induces growth arrest of hepatoma cells via alteration of mitochondrial gene expression and function. Int J Oncol. 2008;33:969-977.

19. Girón RA, Montaño LF, Escobar ML, López-Marure R. Dehydroepiandrosterone inhibits the proliferation and induces the death of HPV-positive and HPV-negative cervical cancer cells through an androgen- and estrogen-receptor independent mechanism. FEBS J. 2009;276:5598-5609.

20. López-Marure R, Contreras PG, Dillon JS. Effects of dehydroepiandrosterone on proliferation, migration, and death of breast cancer cells. Eur J Pharmacol. 2011;660:268-274.

21. Liu S, Ishikawa H, Li FJ, Ma Z, Otsuyama Kl, Asaoku H, Abroun S, Zheng $\mathrm{X}$, Tsuyama $\mathrm{N}$, Obata $\mathrm{M}$, Kawano MM. Dehydroepiandrosterone can inhibit the proliferation of myeloma cells and the interleukin- 6 production of bone marrow mononuclear cells from patients with myeloma. Cancer Res. 2005;65:2269-2276. 
22. Mosmann T. Rapid colorimetric assay for cellular growth and survival: application to proliferation and cytotoxicity assays. J Immunol Methods. 1983;65:55-63.

23. Liu K, Liu P, Liu R, Wu X. Dual AO/EB staining to detect apoptosis in osteosarcoma cells compared with flow cytometry. Med Sci Monit Basic Res. 2015;21:15.

24. Liang CC, Park AY, Guan JL. In vitro scratch assay: A convenient and inexpensive method for analysis of cell migration in vitro. Nat Protoc. 2007;2:329-333.

25. Longo-Sorbello GSA, Saydam G, Banerjee D, Bertino JR. Cytotoxicity and cell growth assays [Internet]. In: Cell Biology, Four-Volume Set. 2006:315-324.

26. Nobes CD, Hall A. Rho GTPases control polarity, protrusion, and adhesion during cell movement. J Cell Biol. 1999;144:1235-1244. Available from: https://rupress.org/jcb/article-abstract/144/6/1235/16076

27. Okabe T, Haji M, Takayanagi R, Adachi M, Imasaki K, Kurimoto F, Watanabe T, Nawata $H$. Up-regulation of high-affinity dehydroepiandrosterone binding activity by dehydroepiandrosterone in activated human $T$ lymphocytes. J Clin Endocrinol Metab. 1995;80:2993-2996.

28. Tworoger SS, Hankinson SE. Prolactin and breast cancer etiology: an epidemiologic perspective. J Mammary Gland Biol Neoplasia. 2008;13:4153.

29. Yoshida S, Honda A, Matsuzaki Y, Fukushima S, Tanaka N, Takagiwa A, Fujimoto Y,Miyazaki H, Salen G. Anti-proliferative action of endogenous dehydroepiandrosterone metabolites on human cancer cell lines. Steroids. 2003;68:73-83.

30. Michels KA, Brinton LA, Wentzensen N, Pan K, Chen C, Anderson GL, Pfeiffer RM, Xu X, Rohan TE, Trabert B. Postmenopausal androgen metabolism and endometrial cancer risk in the women's health initiative observational study. JNCI Cancer Spectr. pkz029. doi: 10.1093/jncics/ pkz029

31. Freedman RS, Pihl E, Kusyk C, Gallager HS, Rutledge F. Characterization of an ovarian carcinoma cell line. Cancer. 1978;42:2352-2359.

32. Hernandez L, Kim MK, Lyle LT, Bunch KP, House CD, Ning F, Noonan AM, Annunziata CM. Characterization of ovarian cancer cell lines as in vivo models for preclinical studies. Gynecol Oncol. 2016;142:332-340.

33. Galley HF, Webster NR. Physiology of the endothelium. Br J Anaesth. 2004;93:105-113.
34. Chien S. Mechanotransduction and endothelial cell homeostasis: The wisdom of the cell. Am J Physiol Heart Circ Physiol. 2007:H1209-H1224.

35. Liu L, Wang D, Li L, Ding X, Ma H. Dehydroepiandrosterone inhibits cell proliferation and improves viability by regulating $S$ phase and mitochondrial permeability in primary rat Leydig cells. Mol Med Rep. 2016;14:705-714.

36. Joshi K, Hassan SS, Ramaraj P. Differential biological effects of dehydroepiandrosterone (DHEA) between mouse (B16F10) and human melanoma (BLM) cell lines. Dermatoendocrinol. 2017;9:e1389360.

37. Chu N, Gui Y, Qiu X, Zhang N, Li L, Li D,Tang W, Gober HJ, Zhang B, Wang $L$. The effect of DHEA on apoptosis and cohesin levels in oocytes in aged mice. Biosci Trends. 2017;11:427-438.

38. Kim HH, Shaipanich M, Hasselblatt K, Yeh J. Induction of apoptosis and ovarian cyst formation in the mouse ovary by dehydroepiandrosterone (DHEA). J Med. 2003;34:101-112.

39. Sozen B, Ozekinci M, Erman M, Gunduz T, Demir N, Akouri R. Dehydroepiandrosterone supplementation attenuates ovarian ageing in a galactose-induced primary ovarian insufficiency rat model. J Assist Reprod Genet. 2019;36:2181-2189.

40. Ding $X, Y u L, G e C, M a H$. Protective effect of DHEA on hydrogen peroxide-induced oxidative damage and apoptosis in primary rat Leydig cells. Oncotarget. 2017;8:16158-16169.

41. Jimenez PT, Frolova Al, Chi MM, Grindler NM, Willcockson AR, Reynolds KA, Zhao Q, Moley KH. DHEA-mediated inhibition of the pentose phosphate pathway alters oocyte lipid metabolism in mice. Endocrinology. 2013;154:4835-4844.

42. Clark BJ, Prough RA, Klinge CM. Mechanisms of Action of Dehydroepiandrosterone. Vitam Horm. 2018:29-73.

43. Ortega-Calderón YN, López-Marure R. Dehydroepiandrosterone inhibits proliferation and suppresses migration of human cervical cancer cell lines. Anticancer Res. 2014;34:4039-4044.

44. Montt-Guevara MM, Shortrede JE, Giretti MS, Giannini A, Mannella P, Russo E, Genazzani AD, Simoncini T. Androgens regulate T47D cells motility and invasion through actin cytoskeleton remodeling. Front Endocrinol (Lausanne). Front Endocrinol (Lausanne). 2016;7:136. 